\title{
Fontes de Contaminação por Estafilococos no Leite Cru no Momento da Ordenha
}

Magali Pozza (I), Karina Maia (I), Geraldo Tadeu dos Santos (I), Grasiele Scaramal Madrona (I), Thomer Durman (I), Augusto Cesar

Favaretto Variani (I), Bruna Susan de Labio Molina (I)

(I) UEM - Universidade Estadual de Maringá (Av colombo 5790 jardim universitario)

\section{Resumo}

O tema qualidade do leite é bastante complexo dado à diversidade do sistema de produção de propriedades e produtores de leite. A mastite contagiosa é causada por micro-organismos bacterianos que incluem Staphylococcus spp. A contaminação ocorre no momento da retirada do leite, pelas mãos do ordenhador e de teteiras na ordenha mecânica. $\mathrm{O}$ objetivo do presente estudo foi avaliar a contaminação do leite em diferentes pontos do processo de ordenha na fazenda experimental da UEM: mãos dos ordenhadores, conjuntos de teteiras, tetos dos animais, leite e tanque de resfriamento com relação à incidência de Staphylococcus ssp. Foram amostrados no momento da ordenha estes pontos de contaminação utilizando-se o Quick Swab ${ }^{\mathrm{TM}}$. Coletaram-se amostras dos 44 tetos dos animais em lactação. Todas as amostras foram semeadas em placas Petrifilm STX ${ }^{\mathrm{TM}}$ para isolamento e confirmação de estafilococos. O material foi processado no laboratório do Centro Meso Regional de Excelência em Tecnologia do Leite localizado na Fazenda Experimental Iguatemi (UEM). As contagens médias obtidas de Staphylococcus spp do tanque foram de $6,45 \times 102 \mathrm{UFC} / \mathrm{ml}$ e do leite individual dos animais de $2,04 \times 102 \mathrm{UFC} / \mathrm{ml}$ valores estes abaixo do necessário para que a toxina estafilocócica provoque intoxicação alimentar. A média de contagem de estafilococos nas teteiras antes e após a higienização foi de 2,12x 102 $\mathrm{UFC} / \mathrm{ml}$, considerando a área das teteiras de $117 \mathrm{~cm} 2$ tem-se o valor de $0,18 \mathrm{UFC} / \mathrm{cm} 2$, inferior aos valores estabelecidos pela APHA para

\footnotetext{
Referência:

Magali Pozza, Karina Maia, Geraldo Tadeu dos Santos, Grasiele Scaramal Madrona, Thomer Durman, Augusto Cesar Favaretto Variani, Bruna Susan de Labio Molina.Fontes de Contaminação por Estafilococos no Leite Cru no Momento da Ordenha. In: Anais do 12 Congresso Latinoamericano de Microbiologia e Higiene de Alimentos - MICROAL 2014 [= Blucher Food Science Proceedings, num.1, vol.1]. São Paulo: Editora Blucher, 2014.

DOI $10.5151 /$ foodsci-microal-120
} 
superfícies que entram em contato com os alimentos. Os valores médios para as mãos dos ordenhadores foram de 4,1 x $102 \mathrm{UFC} / \mathrm{ml}$, sendo que valores inferiores a $102 \mathrm{UFC/ml} \mathrm{são} \mathrm{considerados} \mathrm{ideais.} \mathrm{A} \mathrm{avaliação} \mathrm{da}$ higienização no momento da ordenha é uma ferramenta importante para conhecer as condições sanitárias do rebanho e juntamente com a desinfecção de utensílios, permitem minimizar as perdas econômicas causadas pela mastite e aumentar a segurança alimentar. Agradecimentos: $3 \mathrm{M}$

Palavras-Chave: microbiologia, alimentos, higienização

Agência de Fomento: 